\title{
Two New Case Reports of Propofol Abuse and a Pattern Analysis of the Literature
}

\author{
Mark Welliver, Anita Bertrand, Jennifer Garza, and Kathy Baker
}

Associate Professor of Professional Practice at Texas Christian University School of Nurse Anesthesia, Harris College of Nursing \& Health Sciences, Fort Worth Texas. USA. He also is a Certified Registered Nurse Anesthetist at the University of Florida at Shands Jacksonville, Florida. USA.

E-mail:Mark.welliver@gmail.com

Certified Registered Nurse Anesthetist in Houston Texas. USA. She is an addictions peer-advisor and lectures on addictions and professional practice issues.

E-mail: anita.bertrand@ comcast.net

Certified Registered Nurse Anesthetist in Houston Texas. USA. She is a peerassistance advisor and volunteer peer-supporter.

E-mail: jknjgarza@yahoo.com

Associate Professor with Tenure; Director of the Doctor of Nursing Practice (DNP) and Masters of Science in Nursing (MSN) Programs; Deputy Director of the Center for Evidence Based Practice \& Research: A Collaborating Center of The Joanna Briggs Institute at Texas Christian University Harris College of Nursing \& Health Sciences, Fort Worth Texas. USA.

\section{E-mail: kathy.baker@tcu.edu}

\begin{abstract}
Propofol has become the most widely used sedation and anesthetic drug worldwide. Previously it was thought to lack abuse and dependence potential. Increased awareness of actual propofol abuse cases, however, is providing greater understanding of the associated (or perceived) motivations and rewards of propofol abuse. We report the details of two new propofol abuse cases including the motivations for choosing this drug, abuse practices, subjective experiences, and outcomes. An exploration of reported objective and subjective patterns in propofol abuse case reports was conducted using a modified process of thematic (pattern) analysis. These patterns include: healthcare providers are the most frequent propofol abusers,
\end{abstract}


hospital drug diversion is a primary access, abuse regimens consist of frequent injections, there often exists underlying psychological unrest, typically there is a history of prior drug and alcohol abuse, abusers are seeking relief from anxiety and stress along with restful sleep, abusers report a craving desire, death is frequently an outcome, and rehabilitation programs can be effective treatments. We conclude restrictive regulation of propofol is necessary to better monitor and control its abuse.

Keywords: Abuse, Addiction, Dependence Syndrome, Pattern analysis, Propofol, Thematic analysis.

\section{Introduction}

The extent and significance of propofol abuse has been underreported. Although most literature discussing propofol abuse focuses on the specialty of anesthesia, there is a growing awareness within the healthcare community that propofol needs to be regulated as a substance with abuse and dependence potential. In light of the developing understanding of propofol's brain effects, specific animal and human studies disclosing stimulation of the pleasure-reward system, and the subjective effects gleaned from case studies, more proactive steps to control access are needed. The subjective effects of propofol have been described as euphoric, calming, anxiolytic, and restful. It is now known that propofol possesses dependency potential and as such should be labeled a controlled substance by regulatory agencies. We first share two separate cases of propofol abuse by nurse anesthetists which, in many ways, share similar findings with reports by others. Next, an analysis is performed on all known peer-reviewed case reports of propofol abuse using a thematic analysis approach.[1] Finally, findings are discussed and recommendations made regarding management of propofol in the practice setting.

\section{Case \#1 Propofol Abuse}

Case \#1 involves a 42 year-old female nurse anesthetist. She has been a practicing nurse anesthetist for six years. This individual was a non-smoker, and consumed alcohol socially. She had no past medical history of substance abuse or illicit substance experimentation. The self-disclosed suspected trigger for substance abuse developed after a 24-hour infusion of local anesthetic and fentanyl via an epidural catheter post total abdominal hysterectomy. The epidural analgesia infusion was ropivacaine at $10 \mathrm{cc} / \mathrm{hr}$ along with fentanyl at a rate of $100 \mathrm{mcg} / \mathrm{hr}$. Over 24 hours, a total of 2400 mcg of fentanyl (approximately 4-5 times the normal dose as a result of a prescription error) was delivered before the patient complained of excessive sedation and requested that the infusion be stopped.

The patient returned to work after two weeks post-op. Within two weeks of returning to work, fentanyl was diverted and intravenous injection doses of 50$150 \mathrm{mcgs}$ were self-administered. A seven month use of escalating fentanyl doses 
resulted in difficulty obtaining larger quantities of this drug. To attenuate the fentanyl withdrawal symptoms, propofol was diverted and intravenously administered. This individual stated that the withdrawal symptoms were initially thought to be restless leg syndrome as opposed to opiate withdrawal symptoms. Self-reflection by this individual disclosed her denial of opiate abuse/addiction and the lack of considering withdrawal symptoms as the cause of her "restless leg syndrome".

The desire to relieve "stress" related to withdrawal symptoms, fentanyl acquisition difficulties, and the desire to "escape from the realities of life" contributed to continued use of propofol. Propofol became the substitute drug of choice after seven months of fentanyl use. It provided the only "peace" at a time when "life was full of chaos and fear". There was euphoria associated with the first use of propofol in addition to the attenuation of leg shaking opiate withdrawal symptoms.

The daily use of propofol consisted of an initial $50 \mathrm{mg}$ intravenous (IV) bolus to experience euphoria, followed by subsequent variable doses ranging from 50-100 $\mathrm{mg}$. When administered at night, the dosing regimen consisted of an initial 50$100 \mathrm{mg}$ dose for euphoria followed by the remainder of the propofol vial (100-150 $\mathrm{mg}$ ). This 100-150 mg sleep induction dose resulted in a "restful night of sleep". Prior to propofol abuse, the individual suffered insomnia primarily due to leg shaking. Propofol was craved and the daily use was continual unless interrupted by work or family obligations. Propofol injections were self-administered by direct venipuncture or via a self-inserted heplock.

Propofol administrations were performed by this subject at home and in an automobile. Driving an automobile after propofol use resulted in two motor vehicle accidents. After injecting propofol while in her parked motor vehicle, she was found unconscious by a colleague. Suspicion of her drug abuse by this colleague and a family member encouraged her to immediately seek rehabilitation therapy. After 12 weeks of a 14 week in-patient treatment program, this individual returned home for one week to arrange for the required one year of aftercare support group attendance and to assimilate into a 12 step-program with the support of a recovery sponsor. Within four days of returning home, she visited her work setting, diverted several vials of propofol, and relapsed. This resulted in a required return for six more weeks of in-patient therapy. Today, she remains in recovery for six years and abstinent of propofol abuse or other substance abuse. She has successfully returned to practice.

\section{Case \#2 Propofol Abuse}

Case \# 2 involves a 39 year-old female nurse anesthetist, practicing for eight years. This individual was a non-smoker with no previous history of addiction, substance abuse, or illicit substance experimentation. Social alcohol consumption of less than one drink per week and no binge consumptions were disclosed. Initially, ketorolac (Toradol®) was acquired through hospital diversion 
for self-treatment of a painful ankle injury. Ketorolac was administered intramuscularly twice a day for two days followed by twice a day intravascular administrations for two more days. Desire for greater pain relief led to the diversion and use of intravenous fentanyl and morphine. During four to six months of escalating opiate dosages, the increasing quantities of fentanyl and morphine became difficult to obtain. Ease of access to propofol promoted its use, and although opioids were preferred, propofol was increasingly utilized.

Accessibility was the disclosed primary motivator for choosing propofol coupled with the expressed desire to escape "emotional distress, anxiety, and insomnia" thought to be due to both "internal as well as external stressors and increasingly ineffective coping strategies". A sense of "well-being" associated with propofol administration was described, but no euphoric feelings or sexual disinhibition was noted. The perception of "disconnectedness" and unconsciousness were desirable effects. Propofol boluses of $5 \mathrm{cc}(50 \mathrm{mg})$ intravenous (IV) were repeated every 510 minutes as the effects wore off. This cycle was repeated as time and privacy permitted. Hospital "handicapped" restrooms were the primary location chosen as they were private.

Loss of consciousness sometimes resulted in injuries including a dislocated shoulder, black eyes, and multiple bruising. Frequently, injection sites continued to bleed after injection, and blood stains were visible on scrubs. Frequent absences between cases and an incident of unsteady gait with a fall aroused her colleagues' suspicions of substance abuse. Ultimately, an incident of slurred speech in the operating room following a break led colleagues to intervene. During the intervention, the nurse anesthetist admitted that she had a problem, and agreed to get help. An assessment was performed at a local alcohol and chemical dependency facility, and the recommendation was inpatient treatment for 28-30 days. The total length of time from initial abuse until treatment was approximately six months.

Treatment consisted of a four week partial hospitalization program followed by four weeks of outpatient treatment. Outpatient care consisted of peer facilitated meetings once per week, peer-led relapse prevention meetings two to three times a week, and a 12-step recovery program with meetings four to six times per week. After release from the outpatient treatment, the subject returned to work in the preoperative clinic performing pre-anesthesia assessments. A month later, she entered one of the hospital operating rooms, obtained several vials of unsecured propofol, and relapsed. The next morning, she voluntarily returned to the treatment facility for assessment and ultimately four more weeks of outpatient treatment. After treatment, the subject worked in a business office for several years before returning to clinical work. Today, she is seven years abstinent of propofol abuse, continues to attend 12 step recovery meetings while working with others affected by the disease of addiction, and shares "gratefulness for the opportunity to have a second chance at life". 


\section{Commentary}

These two case reports are similar in that both individuals are nurse anesthetists who initially diverted opiate drugs for abuse prior to using propofol. Propofol became a drug of choice because of its ease of access. The users disclosed propofol effects (rewards) as pleasant feelings of escape, calm, rest, and sleep. These pleasant feelings were given a high priority in their lives and they lacked the ability to discontinue use despite personal injury and professional impairment. The importance given to propofol use affected both individuals and others. Both cases met the diagnosis requirements for dependence syndrome.

Dependence syndrome is formally defined by the World Health Organization in The Tenth Revision of the International Classification of Diseases and Health Problems (ICD-10) as "being a cluster of physiological, behavioral, and cognitive phenomena in which the use of a substance or a class of substances takes on a much higher priority for a given individual than other behaviors that once had greater value".[2] A diagnosis of dependence syndrome may be made if at least three of the following six criteria are present within the preceding year:

1. a strong desire to take the drug

2. impaired control over its use

3. persistent use despite harmful consequences

4. higher priority given to drug use than to other activities and obligations

5. increased tolerance

6. physical withdrawal reaction when drug use is discontinued [2]

Criteria 1-4 has been clearly described in both case reports with typical craving, need, drug seeking behavior, impaired control over use of the drug (propofol), and persistent use despite harmful consequences. These effects are typical of those seen with other drugs possessing dependence potential such as opiates. Increased tolerance has not been disclosed in these two cases although the high doses administered are suspect. It is not known if the previous opiate abuses have increased the tolerance to higher doses of propofol.

Propofol doses in excess of $50 \mathrm{mg}$ for adult individuals are frequently accompanied by loss of airway patency and/or apnea. Doses of 100-200 mg are typically used for inducing general anesthesia. Regardless, the lack of tolerance (requiring increased doses for the same effect) does not make propofol less dangerous as the dose for effect already lies close to the dose for respiratory and cardiac suppression. No withdrawal reactions were disclosed related to propofol abuse in these two cases. The finding that propofol abuse qualifies as a dependence syndrome in these two case reports, as well as others, is a call to action. 


\section{Objectives}

Full and clear understanding of the prevalence of propofol abuse among healthcare providers is lacking. Nurses and physicians, especially in critical care and operating settings, have immediate access to propofol and as such, our awareness and exploration of this concern is of paramount importance. Specific details of propofol abuse by healthcare workers and lay people are needed to fully assess the magnitude and significance of this concern and guide appropriate action. The existing literature in the form of case reports is rich with information that sheds greater understanding regarding this issue and can direct further research into the concern of propofol abuse.

In response, 19 case reports[3-24], including the two disclosed here, were collected for review and categorization of patterns of abuse. Using Braun and Clarke's thematic analysis methodology[1], the use of third party disclosure of case reports precluded direct assumption of patterns as necessarily true selfreported themes. Thematic analysis is a well-known qualitative research methodology that pulls "themes" from direct or transcripted interviews [1]. We therefore used a modified Braun and Clarke's process to identify and categorize described patterns as opposed to self-reported themes common among the 19 disclosed cases of propofol abuse. The general research questions for this study were: 1) what are the common patterns among the case reports of propofol abuse, and 2) do they reflect propofol as a drug with dependence potential?

\section{Methodology}

A repeated search strategy over a 19 month period between August 2009 and March 2011 for peer-reviewed and non-peer-reviewed articles exploring propofol abuse and dependence was conducted. The databases utilized included PubMed, CINAHL, Google, and Google Scholar. Articles were retrieved based on title and/or abstract relevance to propofol abuse, and dependence. Specific search terms reviewed in the title or abstract included: 'propofol' or 'diisopropylphenol' along with 'abuse,' 'addiction,' 'dependence,' 'fatality,' 'death,' 'misuse,' or 'withdrawal.' Inclusion criteria for analysis were peer-reviewed case reports/studies/or correspondence with specific propofol abuse case details. All languages were included. Excluded from the analysis but used for subject review were all other relevant literature found meeting the search terms. These included press releases, news media, and websites of professional organizations.

Nineteen full articles were retrieved. Two of these articles were discarded as one described only euphoric effects during legitimate therapeutic use and the other case described propofol use in a homicide. The 17 peer-reviewed case reports or case descriptions (letter to editors and correspondences), in addition to the two cases reported here, were used for analysis. It is important to note that in addition to the 19 analyzed case reports, many additional cases of propofol abuse are 
known in the literature but lack specific focus or details of the abuse needed for analysis. [25-27]

Analysis of the case reports was conducted using Braun and Clarke's process of thematic analysis.[1] This process consists of six phases: "1. Familiarizing yourself with your data: Transcribing data (if necessary), reading and re-reading the data, noting down initial ideas. 2. Generating initial codes: Coding interesting features of the data in a systematic fashion across the entire data set, collating data relevant to each code. 3. Searching for themes: Collating codes into potential themes, gathering all data relevant to each potential theme. 4. Reviewing themes: Checking if the themes work in relation to the coded extracts (Level 1) and the entire data set (Level 2), generating a thematic 'map' of the analysis. 5. Defining and naming themes: Ongoing analysis to refine the specifics of each theme, and the overall story the analysis tells, generating clear definitions and names for each theme. 6. Producing the report: The final opportunity for analysis, selection of vivid, compelling extract examples, final analysis of selected extracts, relating back of the analysis to the research question and literature, producing a scholarly report of the analysis." $[1$ pg 87] The 19 case reports were thoroughly reviewed and re-reviewed as described in phase 1. The categories that emerged from the literature (phase 2) included: subject demographics, propofol access, regimens of abuse, underlying psychological unrest, prior drug abuse, subjective feelings or effects, and outcomes. Phases 3-5 organized and clarified the data and identified and collated the patterns which were systematized for the phase 6 report.

\section{Findings}

The categories (demographics, access, regimens of abuse, underlying psychological unrest, prior drug abuse, subjective feelings or effects, and outcomes) were further collated and analyzed (Table 1). Our analysis revealed healthcare providers are disproportionately represented in these case studies compared to lay people. Hospital drug diversion is the most frequently described access for obtaining propofol and has been described as "easy to obtain." Regimens of propofol abuse included frequent repetitive IV injections of doses ranging from 50-200 mg, psychological/emotional unrest, and prior substance abuse. All cases described or disclosed performance deterioration, harm, or injury. Death occurred with high incidence $(n=9,50 \%)$ among the documented cases and for survivors, in- or out-patient rehabilitation therapy has been employed. Data (phase 6) of the analysis is summarized in Table 2 and further expounded in the discussion. 


\section{Discussion}

6.1 Demographics and access. It is apparent from review of the case reports that healthcare providers are disproportionately represented among propofol abusers. Related to this disproportion is the access of propofol by drug diversion. Ease of access is frequently identified. Of the 19 case reports, two individuals used fraudulent prescriptions to obtain a supply for patient use and then diverted for personal use. Contrastingly, 15 were by known or assumed hospital drug diversions. Nurses, physicians, and other healthcare workers are exposed to propofol in their work settings because of its widespread use throughout the facility and its current lack of consistent accountability. Inventories of propofol that are loosely monitored allow for ease of drug acquisition and prevent full disclosure of diversion when it occurs.

6.2 Regimens of abuse. Regimens of propofol abuse include intravenous bolus injections of 50-200 $\mathrm{mg}$ followed by sedation, unconsciousness, and then awakening (table 3). This regimen is repeated many times at one binge or throughout the day. The need for privacy and available time for propofol's effects were frequently disclosed in the case reports. Privacy likely accounts for abuse occurring in call rooms, bathrooms, and automobiles. Two disclosures specifically stated that the feeling of privacy within their automobiles encouraged their abuse in that setting (Welliver personal communication, 2010). These two particular cases resulted in automobile accidents and serious injury to both individuals, with fortunately no harm to others. The correspondence by Odell [3] similarly described the injection of propofol by three medical technicians while driving. Frequent injections of propofol by individuals in isolated localities or within automobiles is extremely dangerous to self and others. Propofol's pronounced and short duration of effects in conjunction with its narrow therapeutic window makes its abuse an alarming concern. All cases of propofol abuse disclosed decreased individual task performance.

6.3 Underlying psychological unrest. Psychological distress was frequently associated with propofol abuse. Disclosed desires or motivators for propofol abuse included desire for escape, rest, sleep, and relief of stress and anxiety. Psychiatrist Dr. Omar S. Manejwala, an addiction expert and Director of the addiction treatment center at Farley Center at Williamsburg Place, states "Many individuals who are addicted to Diprivan (propofol) also suffer from PostTraumatic Stress Disorder (PTSD).[28] Most commonly, these individuals are initially attempting to self-medicate refractory, persistent insomnia. This insomnia can be due to any number of causes including depression, PTSD, alcoholism or addiction to other agents".[28] Insomnia is treated effectively by propofol and animal research shows that sleep induced by propofol is restorative and mimics some natural sleep stages .[24] This characteristic of propofol may be useful as a controlled treatment for insomnia, but a peril if self-administered. The underlying 
psychological unrest common among propofol abusers is a subject that is worthy of in-depth study.

6.4 Prior substance use. Previous substance abuse was known in half the case reports. Only three reports specifically stated there was no previous substance abuse. Specific details regarding prior substance abuse are lacking in the case reports reviewed; this is identified as an area for continued exploration regarding the relationship of prior substance abuse to propofol as a drug of choice or escalation. Increasing tolerance to opiates coupled with difficulty in obtaining increasing quantities has been disclosed as reasons for switching to propofol as a drug of abuse in our two new case reports. Ease of access to propofol compared to narcotics was disclosed by both anesthetists in our case reports. Does ease of access to propofol promote its use as a drug of abuse? Our analysis of all cases shows few individuals sought propofol as a first choice drug. Propofol has been described as the primary (first) drug choice in only three cases. [5,6,7] Prior substance abuse was present in half of the case reports. The ease of access is suspected as a factor for healthcare workers.

6.5 Subjective effects. Described feelings and subjective effects associated with propofol abuse include relief of anxiety, stress alleviation, calm feelings, and restful sleep. These disclosed effects can be viewed by abusers as therapeutic and beneficial in light of the previous findings of underlying psychological unrest. Anxiety and insomnia may be symptoms of depression. [8] Many have hypothesized that drug abuse is an attempt to self-treat an underlying psychological disorder. [9] An argument can be made that propofol abuse is an attempt to self-treat anxiety, stress, and/or insomnia. Pharmacologic treatment of psychological disorders is not advised, possibly illegal, and in the case of propofol, highly dangerous.

6.7 Outcome. The incidence of death was over a third of the reported cases. Overdose leading to respiratory arrest and cardiac arrest were the suspected causative events responsible for death. The narrow therapeutic window between sedation and significant respiratory depression likely accounts for the high incidence of death related to propofol abuse in these case studies. Recovery experts and therapists have seen a growing incidence of in-patient and out-patient admissions for propofol abuse.[10] In cases where death was not the final outcome, in- and out-patient therapy was found to be effective for rehabilitation. Relapse, however, was common (Table 2 outcomes).

\section{Limitations}

This case study analysis is limited by inconsistencies in the disclosed case reports. Full pattern prevalence and analysis was not possible, particularly concerning subjective effects due to the high death rate. What is not known is if case reports are skewed toward death (i.e. suicide or overdose) as an outcome because the abuse can no longer be hidden. The true incidence of propofol abuse 
is unknown but it is greater than that described by the literature. There are at least 45 known peer-revealed disclosures of propofol abuse. Our findings provide some clarity and suggest areas for further formal inquiry. Despite the incomplete picture provided by these findings, the evidence is compelling that propofol has dependence potential.

\section{Recommendations}

Considering the growing body of evidence regarding propofol's dependence potential and associated high death rate, preventative strategies should be considered. The standard for promoting or implementing new therapeutic practices should require greater scrutiny of the evidence than that for preventative strategies. We recommend preventative strategies based on the review of case reports. The case reports of propofol as a drug with dependence potential is compelling and meets the criteria established by the WHO.[1] Furthermore, the United States Drug Enforcement Agency Controlled Substances Act specifically addresses the concerns expounded here. (Table 3) A proposed rule to place propofol into schedule IV as a restricted controlled substance is supported by our findings.[29] The prevention of abuse by restriction of access, signature accountability, and education of risks is unlikely to do harm and will address these serious concerns. Restrictive policies for propofol access and use in all jurisdictions worldwide need to be enacted and supported. Suggested recommendations are listed in Table 4.

The identification, documentation, and dissemination of propofol abuse cases along with continued study of its dependence potential is needed. Restrictive access and signature accountability for propofol is necessary, especially considering the high incidence of death with propofol abuse. Will these strategies decrease what appears to be an underreported and minimally addressed abuse concern? Or will they merely enable better tracking and data collection to realize the full extent of propofol abuse? Further study and assessment of the issues surrounding propofol abuse, particularly among nurses, needs to be conducted.

The patterns among propofol abuse in these case reports disclose important findings that may be considered within the nursing profession and among policy making organizations. The Drug Enforcement Agency (DEA) has disclosed their intent to place schedule IV controlled substance labeling on propofol and this regulation alone will bring much needed protections within the United States. [30]

\section{Conclusion}

Health care providers must be advocates for each other just as we are for our patients. Based on the analysis of 19 cases of reported propofol abuse, we are encouraged to promote and support accountability policies that include restricted access to locked and monitored inventories of propofol with authorized signature 
required for release. Documentation of remaining propofol amounts when transferring care of patients with propofol infusions should also be conducted. Pharmacy return of propofol waste for proper disposal or two person signature waste confirmation should be considered. Full accounting of propofol inventories, use, and waste should be supported by all healthcare workers and policy makers. Our greater understanding of propofol's dependence potential coupled with knowledge gleaned from actual abuse cases warrants this new perspective and policy direction as well as further study.

\section{Acknowledgements}

Authors thank and appreciate translation services provided by Sylvia Gabbard, Administrative Manager Department of Anesthesiology University of Florida College of Medicine - Jacksonville and Kristina Heilinger, nursing and care management student at Paracelsus University Salzburg Austria.

\section{References}

[1] Braun, V., \& Clarke, V. (2006). Using thematic analysis in psychology. Qualitative Research in Psychology, 3,77-101.

[2] World Health Organization (WHO). (2010). Dependence syndrome. Available at: http://www.who.int/substance_abuse/terminology/definition1/en/. Accessed Dec. 20, 2010.

[3] Odell, M. (1999). Propofol abuse (correspondence letter). Anaesthesia and Intensive Care, 27, 539.

[4] Tung, A., Bergman, B., Herrera, S., Cao, D., \& Mendelson, W. (2004). Recovery from sleep deprivation occurs during propofol anesthesia. Anesthesiology, 100 (6), 1419-1426.

[5] Koopman, A., von der Goltz, C., Hermann, D., \& Kiefer, F. (2011). Propofol addiction initiated by anesthetic use. American Journal of Psychiatry, 168, 2.

[6] Schneider, U., Rada, D., Rollnik, J. D., Passie, T., \& Emrich, H. M. (2001). Propofol dependency after treatment of tension headache. Addiction Biology,. 6, 263-265.

[7] Soyka, M., \& Schütz, C. G. (1997). Propofol dependency (letter). Addiction, 92, 1369-1370.

[8] Soldatos, C. R. (1994). Insomnia in relation to depression and anxiety: Epidemiologic considerations. Journal of Psychosomatic Research, 38 (1), 38.

[9] Weiss, R. D., Griffin, M. L., \& Mirin, S. M. (1992). Drug abuse as selfmedication for depression: An empirical study. American Journal of Drug and Alcohol Abuse, 18(2), 121-129

[10] Marcus, A. (2007). Propofol abuse a growing problem for anesthesiologists. Anesthesiology News, 33 (05). Accessed March 9, 2011. Available at 
http://www.anesthesiologynews.com/ViewArticle.aspx?d_id=1\&a_id=7579 \&ses $=$ ogst.

[11] Bonnet, U., Harkener, J., Scherbaum, N. (2008). A case report of propofol dependence in a physician. Journal of Psychoactive Drugs, 40,215-217.

[12] Chao, T. C., Lo, D. S. T., Chui, P. P. S., \& Koh, T. H. (1994). The first fatal 2,6-di-isopropylphenol (propofol) poisoning in Singapore: A case report. Forensic Science International, 66, 1-7.

[13] Cirimele, V., Kintz, P., Doray, S., \& Lutes, B. (2002). Determination of chronic abuse of the anesthetic agents midazolam and propofol as demonstrated by hair analysis. International Journal of Legal Medicine, 116, 54-57.

[14] Drummer, O. H. (1992). A fatality due to propofol poisoning. Journal of Forensic Science, 37, 1186-1189.

[15] Follette, J. W., \& Farley, W. J. (1992). Anaesthesiologist addicted to propofol. Anesthesiology, 77, 817-818.

[16] Fritz, G. A., \& Niemczyk, W. E. (2002). Propofol dependency in a lay person. Anesthesiology, 96, 505-506.

[17] Gundel, H., \& Kuhs, H. (1992). Kasuistische Mitteilung uber neuntagigen Propofol-Mibrauch. Anaesthesiol. Intensivmed. Schmerztherap, 27, 181182.

[18] Iwersen-Bergmann, S., Rosner, P., Kuhnau, H. C., Junge, M., \& Schmoldt, A. (2001). Death after excessive propofol abuse. International Journal of Legal Medicine,114, 248-251.

[19] Klausz, G., Rona, K., Kristof, I., \& Toro, K. (2009). Evaluation of a fatal propofol intoxication due to self administration. Journal of Forensic and Legal Medicine, 16, 287-289.

[20] Kranioti, E. F., Mavroforou, A., Mylonakis, P., \& Michalodimitrakis, M. (2007). Lethal self administration of propofol (Diprivan) : A case report and review of the literature. Forensic Science International, 167, 56-58.

[21] Lee, S. I., \& Yoo, S. H. (2009). Fatal factors related to abuse of propofol (Diprivan) A case report and review of the literature. Korean Journal of Legal Medicine, 33, 70-73.

[22] Roussin, A., Mirepoix, M., Lassabe, G. Dumestre-Toulet, V., Gardette, V., Montastruc, J-L., \& Lapeyre, -Mestre, M. (2006). Death related to a recreational abuse of propofol at therapeutic dose range. British Journal of Anaesthesia,. 97, 268.

[23] Strehler, M., Preub, J., Wollersen, H., \& Madea, B. (2006). Letalepropofolmischintoxikation bei einem medizinischen laien. Archiv fur Kriminologie, 217, 153-160.

[24] Tung, A., Lynch, J. P., \& Mendelson, W. B. (2001). Prolonged Sedation with Propofol in the rat does not result in sleep deprivation. Anesthesia Analgesia, 92 (5), 1232-1236. 
[25] Riezzo, I., Centini, F., Neri, M., Rossi, G., Spanoudaki, E., Turillazzi, E., \& Fineschi, V. (2009). Brugada-like EKG pattern and myocardial effects in a chronic propofol abuser. Clinical Toxicology 47,358-363.

[26] Wischmeyer, P. E., Johnson, B. R., Wilson, J. E., Dingmann, C., Bachman, H. M., Roller, E., Tran, Z. V., \& Henthorn, T. K. (2007). A survey of propofol abuse in academic anesthesia programs. Anesthesia \& Analgesia, 105, 1066-1071.

[27] Weetman, D. B., Mascardo, L. A., Ross, M. B., \& Abramowitz, P. W. (2004). Propofol as a drug of diversion. American Journal of Health-System Pharmacy, 61, 1185-1186.

[28] Farley Center. (2009). Omar S. Manejwala, MD speaks out nationally on diprivan/propofol abuse (press release). Available at: http://www.prweb.com/releases/FarleyCenter/Diprivan/prweb2653044.htm. Accessed Dec. 20, 2010

[29] Federal Register. (2010). Schedules of controlled substances: Placement of propofol into schedule IV. A proposed rule by the drug enforcement administration on 10/27/2010. Accessed Feb. 7, 2010. Available at: http://www.federalregister.gov/articles/2010/10/27/2010-27193/schedulesof-controlled-substances-placement-of-propofol-into-schedule-iv

[30] United States Drug Enforcement Agency. Title 21 - Food and drugs. Chapter 13-Drug abuse prevention and control. Available at: http://uscode.house.gov/download/pls/21C13.txt Accessed Aug 26, 2011.See also: AANA position statement on securing propofol. Available at: http://www.aana.com/workArea/DownloadAsset.aspx?id=26613

[31] ation Methods, John Wiley, New York, 1973. 
Table 1 Categories and Pattern Findings of Documented Cases of Propofol Abuse

\begin{tabular}{|c|c|c|c|c|c|c|c|c|}
\hline Reference & $\begin{array}{c}\text { Type } \\
\text { of } \\
\text { Report }\end{array}$ & Subject & Access & Regimen & $\begin{array}{c}\text { Psychological } \\
\text { Unrest }\end{array}$ & $\begin{array}{c}\text { Prior Drug } \\
\text { Use }\end{array}$ & $\begin{array}{c}\text { Subjective } \\
\text { Effects }\end{array}$ & Outcome \\
\hline $\begin{array}{l}\text { Bonnet et } \\
\text { al. (2008) }\end{array}$ & $\begin{array}{l}\text { Case } \\
\text { report }\end{array}$ & $\begin{array}{l}\text { Male physician } \\
\text { (age 30) }\end{array}$ & Clinic diversion & $\begin{array}{l}\text { Up } 15 \text { x daily } \\
\text { (400 mg } \\
\text { daily) }\end{array}$ & $\begin{array}{l}\text { Periodic cluster } \\
\text { headaches, } \\
\text { anxiety }\end{array}$ & $\begin{array}{l}\text { Prior tobacco, } \\
\text { marijuana, } \\
\text { ETOH, and } \\
\text { benzodiazepine } \\
\text { abuse. }\end{array}$ & $\begin{array}{l}\text { Pleasant, } \\
\text { euphoric, } \\
\text { craving, } \\
\text { tolerance, } \\
\text { withdrawal. }\end{array}$ & $\begin{array}{l}\text { Short term } \\
\text { rehabilitation } \\
\text { relapse, long } \\
\text { term } \\
\text { rehabilitation }\end{array}$ \\
\hline $\begin{array}{l}\text { Chao et al. } \\
\text { (1994) }\end{array}$ & $\begin{array}{l}\text { Case } \\
\text { report }\end{array}$ & $\begin{array}{l}\text { Male physician } \\
\text { (age 37) }\end{array}$ & $\begin{array}{l}\text { Assumed } \\
\text { diversion }\end{array}$ & $\begin{array}{l}\text { Overdose, } \\
\text { infusion, } \\
\text { found empty: } \\
8 \text { propofol, } 6 \\
\text { Ca gluconate, } \\
5 \text { KCL vials }\end{array}$ & $\begin{array}{l}\text { Emotionally upset } \\
\text { related to failed } \\
\text { relationship, } \\
\text { suspected } \\
\text { depression }\end{array}$ & Unknown & Suicide & $\begin{array}{l}\text { Death, } \\
\text { overdose, } \\
\text { ruled suicide }\end{array}$ \\
\hline $\begin{array}{l}\text { Cirimele } \\
\text { et al. } \\
(2002)\end{array}$ & $\begin{array}{l}\text { Case } \\
\text { report }\end{array}$ & $\begin{array}{l}\text { Female nurse } \\
\text { (age 44) }\end{array}$ & $\begin{array}{l}\text { Assumed } \\
\text { diversion }\end{array}$ & $\begin{array}{l}\text { Overdose, } \\
\text { found empty } \\
\text { midazolam } \\
\text { vial } \\
(5 \mathrm{mg} / 5 \mathrm{ml}) \\
\text { and syringe }\end{array}$ & Unknown & $\begin{array}{l}\text { Poly-substance } \\
\text { abuse for } \\
\text { years. } \\
\text { (propofol, } \\
\text { midazolam, } \\
\text { ethanol) }\end{array}$ & Unknown & $\begin{array}{l}\text { Death, } \\
\text { overdose }\end{array}$ \\
\hline $\begin{array}{l}\text { Drummer } \\
\text { (1992) }\end{array}$ & $\begin{array}{l}\text { Case } \\
\text { report }\end{array}$ & $\begin{array}{l}\text { Female } \\
\text { physician } \\
\text { radiographer } \\
\text { (age 29) }\end{array}$ & $\begin{array}{l}\text { Assumed } \\
\text { diversion }\end{array}$ & $400 \mathrm{mg}$ IV & Unknown & Unknown & Unknown & $\begin{array}{l}\text { Death, } \\
\text { overdose }\end{array}$ \\
\hline $\begin{array}{c}\text { Follette \& } \\
\text { Farley } \\
\text { (1992) }\end{array}$ & $\begin{array}{l}\text { Case } \\
\text { report }\end{array}$ & $\begin{array}{l}\text { Physician } \\
\text { anesthesiologist } \\
\text { (Age 30+) }\end{array}$ & $\begin{array}{l}\text { Hospital drug } \\
\text { diversion }\end{array}$ & $\begin{array}{l}100 \mathrm{mg} \mathrm{IV} \\
\text { bolus x 10-15 } \\
\text { daily }\end{array}$ & Stress, depression & $\begin{array}{l}\text { Prior poly- } \\
\text { substance } \\
\text { abuse for years } \\
\text { (midazolam, } \\
\text { fentanyl, } \\
\text { propofol) }\end{array}$ & $\begin{array}{l}\text { Desired stress } \\
\text { reduction and } \\
\text { clear headedness } \\
\text { after } 10 \text { minute } \\
\text { induced sleep }\end{array}$ & $\begin{array}{l}\text { Long-term } \\
\text { drug } \\
\text { rehabilitation } \\
\text { program }\end{array}$ \\
\hline Fritz \& & Case & Male lay & Initial & $50 \mathrm{mg} \mathrm{IV}$ & Tension headache & Prior drug & Relaxed sleep & 7 day in- \\
\hline
\end{tabular}




\begin{tabular}{|c|c|c|c|c|c|c|c|c|}
\hline $\begin{array}{l}\text { Niemczyk } \\
\text { (2002) }\end{array}$ & report & person (age 31) & $\begin{array}{l}\text { prescription } \\
\text { from } \\
\text { anesthesiologist, } \\
\text { additional } \\
\text { prescriptions } \\
\text { from } \\
\text { veterinarian }\end{array}$ & $\begin{array}{l}\text { bolus x 12-20 } \\
\text { daily }\end{array}$ & $\begin{array}{l}\text { treatment with } \\
\text { propofol, ADHD, } \\
\text { History of } \\
\text { Methylphenhydate } \\
\text { (Ritalin) as child x } \\
1 \text { year }\end{array}$ & $\begin{array}{l}\text { abuse for } \\
\text { years. Used } \\
\text { propofol x } 4 \\
\text { years }\end{array}$ & & $\begin{array}{l}\text { patient } \\
\text { treatment, } \\
\text { refused } \\
\text { further } \\
\text { treatment. }\end{array}$ \\
\hline $\begin{array}{l}\text { Gundel \& } \\
\text { Kuhs } \\
\text { (1992) }\end{array}$ & $\begin{array}{l}\text { Case } \\
\text { report }\end{array}$ & $\begin{array}{l}\text { Male lay } \\
\text { person (age } \\
40 \text { ) }\end{array}$ & Unknown & $\begin{array}{l}50 \mathrm{mg} \text { IV x } 3 \\
\text { doses daily } \\
\text { (150 mg total } \\
\text { daily), } 9 \text { day } \\
\text { binge }\end{array}$ & $\begin{array}{l}\text { Anxiety, inner } \\
\text { tension, } \\
\text { restlessness }\end{array}$ & $\begin{array}{l}\text { Abstinent } \\
\text { alcoholic x } 4 \\
\text { years }\end{array}$ & $\begin{array}{l}\text { Relief of anxiety, } \\
\text { inner tension, } \\
\text { restlessness, } \\
\text { "inner warmth } \\
\text { and quiet" }\end{array}$ & $\begin{array}{l}9 \text { day hospital } \\
\text { treatment } \\
\text { followed by } \\
11 \text { weeks out- } \\
\text { patient } \\
\text { treatment }\end{array}$ \\
\hline $\begin{array}{l}\text { Iwersen- } \\
\text { Bergmann } \\
\text { et al. } \\
(2001)\end{array}$ & $\begin{array}{l}\text { Case } \\
\text { report }\end{array}$ & $\begin{array}{l}\text { Male nurse } \\
\text { (age 26) }\end{array}$ & $\begin{array}{l}\text { Hospital drug } \\
\text { diversion }\end{array}$ & Unknown & Depression & $\begin{array}{l}\text { Prior propofol } \\
\text { and poly- } \\
\text { substance } \\
\text { abuse for years }\end{array}$ & $\begin{array}{l}\text { Prior treatment } \\
\text { for depression x } 6 \\
\text { months }\end{array}$ & $\begin{array}{l}\text { Death, } \\
\text { overdose }\end{array}$ \\
\hline $\begin{array}{l}\text { Koopman } \\
\text { et al. } \\
\text { (2011) }\end{array}$ & Letter & $\begin{array}{l}\text { Female nurse } \\
\text { midwife (age } \\
\text { 34) }\end{array}$ & $\begin{array}{l}\text { Hospital } \\
\text { diversion }\end{array}$ & $\begin{array}{l}\text { Daily } 200 \mathrm{mg} \\
\text { IV bolus x 5- } \\
\text { 7/day for } 1 \\
\text { year }\end{array}$ & $\begin{array}{l}\text { "Variety of } \\
\text { stressors" }\end{array}$ & $\begin{array}{l}\text { No prior drug } \\
\text { or alcohol } \\
\text { abuse }\end{array}$ & $\begin{array}{l}\text { Craving, } \\
\text { euphoria, } \\
\text { relaxation, } \\
\text { multiple prior } \\
\text { propofol } \\
\text { sedations for } \\
\text { colonoscopies }\end{array}$ & $\begin{array}{l}\text { Job loss, drug } \\
\text { abuse } \\
\text { treatment } \\
\text { program }\end{array}$ \\
\hline $\begin{array}{l}\text { Klausz et } \\
\text { al. (2009) }\end{array}$ & $\begin{array}{l}\text { Case } \\
\text { report }\end{array}$ & $\begin{array}{l}\text { Female nurse } \\
\text { anesthetist } \\
\text { (age 42) }\end{array}$ & $\begin{array}{l}\text { Assumed } \\
\text { diversion }\end{array}$ & $\begin{array}{l}\text { Overdose, } \\
\text { found } 14 \\
\text { empty vials, } \\
\text { ampules of } \\
\text { propofol, and } \\
\text { two full } \\
\text { syringes of } \\
\text { propofol }\end{array}$ & Unknown & $\begin{array}{l}\text { Family } \\
\text { reported daily } \\
\text { propofol abuse }\end{array}$ & Unknown & $\begin{array}{l}\text { Death, } \\
\text { overdose }\end{array}$ \\
\hline
\end{tabular}




\begin{tabular}{|c|c|c|c|c|c|c|c|c|}
\hline $\begin{array}{l}\text { Kranioti et } \\
\text { al. (2007) }\end{array}$ & $\begin{array}{l}\text { Case } \\
\text { report }\end{array}$ & $\begin{array}{l}\text { Female } \\
\text { anesthesiologist } \\
\text { (age 38) }\end{array}$ & $\begin{array}{l}\text { Assumed } \\
\text { diversion }\end{array}$ & $\begin{array}{l}\text { Overdose, } \\
\text { found empty: } \\
3 \text { propofol, } 1 \\
\text { lidocaine vial }\end{array}$ & Unknown & $\begin{array}{l}\text { Known } \\
\text { propofol abuse } \\
\text { for months }\end{array}$ & Unknown & $\begin{array}{l}\text { Death, } \\
\text { overdose }\end{array}$ \\
\hline $\begin{array}{l}\text { Lee \& } \\
\text { Yoo } \\
\text { (2009) }\end{array}$ & $\begin{array}{l}\text { Case } \\
\text { report }\end{array}$ & $\begin{array}{l}\text { Male physician } \\
\text { surgeon (age } \\
38 \text { ) }\end{array}$ & $\begin{array}{l}\text { False } \\
\text { prescription }\end{array}$ & $\begin{array}{l}\text { 1 empty } \\
\text { propofol } \\
\text { ampule } \\
\text { diluted in IV } \\
\text { infusion of } \\
\text { LR found } \\
\text { with body }\end{array}$ & Unknown & $\begin{array}{l}\text { Previous abuse } \\
\text { with alcohol } \\
\text { suspected }\end{array}$ & Unknown & $\begin{array}{l}\text { Death, } \\
\text { overdose }\end{array}$ \\
\hline $\begin{array}{l}\text { Odell } \\
\text { (1999) }\end{array}$ & Letter & $\begin{array}{l}\text { Three male } \\
\text { medical } \\
\text { technicians }\end{array}$ & $\begin{array}{l}\text { Hospital drug } \\
\text { diversion }\end{array}$ & $\begin{array}{l}\text { Police } \\
\text { apprehension, } \\
\text { injecting } \\
\text { propofol } \\
\text { while driving } \\
\text { automobiles }\end{array}$ & Unknown & $\begin{array}{l}\text { Prior propofol } \\
\text { abuse }\end{array}$ & Unknown & $\begin{array}{l}\text { "Police } \\
\text { apprehension" } \\
\text { while driving } \\
\text { erratically }\end{array}$ \\
\hline $\begin{array}{l}\text { Roussin et } \\
\text { al. (2006) }\end{array}$ & $\begin{array}{l}\text { Letter } \\
\text { to } \\
\text { Editor }\end{array}$ & $\begin{array}{l}\text { Male nurse } \\
\text { anesthetist (age } \\
\text { 27) }\end{array}$ & Unknown & $\begin{array}{l}\text { Overdose, } 3 \\
\text { empty } \\
\text { propofol vials } \\
\text { found with } \\
\text { body }\end{array}$ & Unknown & $\begin{array}{l}\text { Previous abuse } \\
\text { suspected d/t } \\
\text { multiple } \\
\text { venipuncture } \\
\text { sites }\end{array}$ & Unknown & $\begin{array}{l}\text { Death, } \\
\text { overdose }\end{array}$ \\
\hline $\begin{array}{l}\text { Schneider } \\
\text { et al. } \\
\text { (2001) }\end{array}$ & $\begin{array}{l}\text { Case } \\
\text { report }\end{array}$ & $\begin{array}{l}\text { Male } \\
\text { lay person (age } \\
25 \text { ) }\end{array}$ & $\begin{array}{l}\text { Prescription by } \\
\text { anesthesiologist } \\
\text { for treatment of } \\
\text { tension } \\
\text { headache }\end{array}$ & $\begin{array}{l}\text { Propofol } 200 \\
\text { mg IV } \\
\text { boluses x 10- } \\
15 \text { daily }\end{array}$ & $\begin{array}{l}\text { ADHD, suspected } \\
\text { tension, received } \\
\text { Ritalin as child x } \\
\text { 1year }\end{array}$ & $\begin{array}{l}\text { No prior drug } \\
\text { or alcohol } \\
\text { abuse, used } \\
\text { propofol x } 1 \\
\text { year }\end{array}$ & $\begin{array}{l}\text { Relaxation, mild } \\
\text { euphoria, } \\
\text { relieved tension x } \\
6 \text { months, sexual } \\
\text { dis-inhibition } \\
\text { specifically } \\
\text { denied }\end{array}$ & $\begin{array}{l}\text { Outpatient } \\
\text { psychotherapy }\end{array}$ \\
\hline $\begin{array}{l}\text { Soyka \& } \\
\text { Schütz } \\
\text { (1997) }\end{array}$ & $\begin{array}{l}\text { Letter } \\
\text { to } \\
\text { Editor }\end{array}$ & $\begin{array}{l}\text { Physician (age } \\
31)\end{array}$ & $\begin{array}{l}\text { Hospital drug } \\
\text { diversion }\end{array}$ & $\begin{array}{l}\text { Propofol } 50 \\
\text { mg injections } \\
\text { (up to }\end{array}$ & $\begin{array}{l}\text { Boredom, tension, } \\
\text { depression x } 10 \\
\text { months, }\end{array}$ & $\begin{array}{l}\text { No prior drug } \\
\text { or alcohol } \\
\text { abuse }\end{array}$ & $\begin{array}{l}\text { Mild euphoria, } \\
\text { relaxation, } \\
\text { craving, relieved }\end{array}$ & $\begin{array}{l}\text { Long term in- } \\
\text { patient } \\
\text { abstinence }\end{array}$ \\
\hline
\end{tabular}




\begin{tabular}{|c|c|c|c|c|c|c|c|c|}
\hline & & & & 100x/day) & $\begin{array}{l}\text { narcissistic } \\
\text { personality }\end{array}$ & & $\begin{array}{l}\text { boredom, tension, } \\
\text { depression, } \\
\text { tolerance to } \\
\text { euphoria }\end{array}$ & $\begin{array}{l}\text { treatment; } \\
\text { out-patient } \\
\text { relapse } x 2\end{array}$ \\
\hline $\begin{array}{l}\text { Strehler, } \\
\text { Preub, } \\
\text { Wollersen, } \\
\text { \& Madea } \\
(2006)\end{array}$ & $\begin{array}{l}\text { Case } \\
\text { report }\end{array}$ & $\begin{array}{l}\text { Male lay } \\
\text { person } \\
\text { (firefighter) } \\
\text { (age 21) }\end{array}$ & $\begin{array}{l}\text { Local pharmacy } \\
\text { purchase using } \\
\text { stolen } \\
\text { prescriptions } \\
\text { obtained from } \\
\text { Ebay (internet) }\end{array}$ & $\begin{array}{l}\text { Propofol } \\
\text { injections 4- } \\
\text { 5/day, empty } \\
\text { vial found } \\
\text { with body }\end{array}$ & unknown & $\begin{array}{l}\text { Prior use of } \\
\text { diazepam, } \\
\text { etomidate; } \\
\text { multiple needle } \\
\text { marks on } \\
\text { extremities }\end{array}$ & $\begin{array}{l}\text { Self treatment of } \\
\text { epilepsy } \\
\text { symptoms }\end{array}$ & $\begin{array}{l}\text { Death, } \\
\text { overdose }\end{array}$ \\
\hline $\begin{array}{l}\text { Welliver } \\
\text { personal } \\
\text { com. } \\
\text { (2010) }\end{array}$ & $\begin{array}{l}\text { Case } \\
\text { report } \\
\# 1\end{array}$ & $\begin{array}{l}\text { Female nurse } \\
\text { anesthetist } \\
\text { (age 42) }\end{array}$ & $\begin{array}{l}\text { Hospital } \\
\text { diversion }\end{array}$ & $\begin{array}{l}\text { Daily 50- } \\
\text { 200mg bolus } \\
\text { x } 6+\end{array}$ & "life's stressors" & $\begin{array}{l}\text { Prior fentanyl } \\
\text { abuse, no } \\
\text { prior alcohol } \\
\text { abuse }\end{array}$ & $\begin{array}{l}\text { "Peace", } \\
\text { euphoria, } \\
\text { craving, } \\
\text { withdrawal } \\
\text { symptoms denied }\end{array}$ & $\begin{array}{l}18 \text { weeks in- } \\
\text { patient } \\
\text { treatment, } \\
\text { ongoing } 12 \\
\text { step recovery } \\
\text { program }\end{array}$ \\
\hline $\begin{array}{l}\text { Welliver } \\
\text { personal } \\
\text { com. } \\
(2010)\end{array}$ & $\begin{array}{l}\text { Case } \\
\text { report } \\
\# 2\end{array}$ & $\begin{array}{l}\text { Female nurse } \\
\text { anesthetist } \\
\text { (age 39) }\end{array}$ & $\begin{array}{l}\text { Hospital } \\
\text { diversion }\end{array}$ & $\begin{array}{l}\text { Daily 50mg } \\
\text { IV bolus } x \\
10+\end{array}$ & $\begin{array}{l}\text { "emotional } \\
\text { distress, anxiety, } \\
\text { and insomnia, } \\
\text { "ineffective } \\
\text { coping strategies" }\end{array}$ & $\begin{array}{l}\text { Prior fentanyl } \\
\text { abuse, no prior } \\
\text { alcohol abuse }\end{array}$ & $\begin{array}{l}\text { Escape, } \\
\text { wellbeing, } \\
\text { disconnectedness, } \\
\text { craving, sleep }\end{array}$ & $\begin{array}{l}\text { In-patient } \\
\text { followed by } \\
\text { out-patient } \\
\text { treatment with } \\
12 \text { step } \\
\text { recovery } \\
\text { program }\end{array}$ \\
\hline
\end{tabular}

Table 2 Categories and Pattern Findings Demographics

- Healthcare providers are the most frequent propofol abusers $(n=14,67 \%)$.

- $\quad$ Nurses $(\mathrm{n}=7,33 \%)$

- Physicians $(\mathrm{n}=7,33 \%)$

- Anesthesia providers (MD, CRNAs) $(n=6,28 \%)$ 
Access

- Primary access is hospital drug diversion $(\mathrm{n}=15,71 \%)$.

- False prescription is another mode of $\operatorname{access}(\mathrm{n}=2,10 \%)$.

Regimen of abuse

- Frequent, repetitive injections $(\mathrm{n}=10,48 \%)$

- Punctuated by unconsciousness/awake cycles

Underlying psychological unrest $(n=11,52 \%)$

- Anxiety, stress $(\mathrm{n}=7,33 \%)$

- Depression, insomnia $(\mathrm{n}=4,19 \%)$

Prior substance use $(\mathrm{n}=11,52 \%)$

- $\quad$ Yes $(\mathrm{n}=11,52 \%)$

- $\quad$ No $(n=3,14 \%)$

- Unknown $(\mathrm{n}=2,10 \%)$

- $\operatorname{Narcotics}(\mathrm{n}=3,14 \%)$

- Alcohol $(\mathrm{n}=4,19 \%)$

- Other or poly-substance $(n=7,33 \%)$

Subjective effects (disclosed) $(n=11,61 \%)$

- Relief of anxiety, stress, or depression $(\mathrm{n}=8,38 \%)$

- Induced, restful sleep $(\mathrm{n}=3,14 \%)$

- Euphoria $(\mathrm{n}=5,24 \%)$

- Craving $(\mathrm{n}=5,24 \%)$ 
- Withdrawal $(\mathrm{n}=2,10 \%)$

Outcome

- Performance deterioration, harm, or injury $(n=21,100 \%)$

- Effective I-patient treatment and rehabilitation program $(n=9,43 \%)$

- Death $(\mathrm{n}=9,43 \%)$

Note: Percentages rounded to nearest full value. Total cases 21.

Table 3 US DEA Controlled Substance Schedules

Schedule I. -

(A) The drug or other substance has a high potential for abuse.

(B) The drug or other substance has no currently accepted medical use in treatment in the United States.

(C) There is a lack of accepted safety for use of the drug or other substance under medical supervision.

Schedule II. -

(A) The drug or other substance has a high potential for abuse.

(B) The drug or other substance has a currently accepted medical use in treatment in the United States or a currently accepted medical use with severe restrictions.

(C) Abuse of the drug or other substances may lead to severe psychological or physical dependence. 
Schedule III. -

(A) The drug or other substance has a potential for abuse less than the drugs or other substances in schedules I and II.

(B) The drug or other substance has a currently accepted medical use in treatment in the United States.

(C) Abuse of the drug or other substance may lead to moderate or low physical dependence or high psychological dependence.

Schedule IV. -

(A) The drug or other substance has a low potential for abuse relative to the drugs or other substances in schedule III.

(B) The drug or other substance has a currently accepted medical use in treatment in the United States.

(C) Abuse of the drug or other substance may lead to limited physical dependence or psychological dependence relative to the drugs or other substances in schedule III.

Schedule V. -

(A) The drug or other substance has a low potential for abuse relative to the drugs or other substances in schedule IV.

(B) The drug or other substance has a currently accepted medical use in treatment in the United States. 
(C) Abuse of the drug or other substance may lead to limited physical dependence or psychological dependence relative to the drugs or other substances in schedule IV.

Table 4 Summary of Suggested Recommendations for Management of Propofol

- Awareness education of propofol abuse and dependence potential

- Federal restrictive scheduling of propofol

- Locked access to propofol inventories

- Mandatory in-patient treatment for propofol abuse

- Ongoing drug dosage accounting with witness signature for all patients transferred with propofol infusions

- Signature accountability for propofol use

- Use of locked infusion devices similar to that used for patient controlled analgesia

- Witnessed waste or pharmacy return of all unused propofol

- Zero tolerance policies that are non-punitive with supportive interventions that focus on propofol abuse as a symptom of disease 